\title{
Phylogenetics of the freshwater crab (Potamonautes MacLeay, 1838) fauna from 'sky islands' in Mozambique with the description of a new species (Brachyura: Potamoidea: Potamonautidae)
}

\author{
Savel R. DANIELS ${ }^{1, *}$, Gabriela B. BITTENCOURT-SILVA ${ }^{2}$, Vanessa MUIANGA ${ }^{3} \&$ \\ Julian BAYLISS ${ }^{4}$ \\ ${ }^{1}$ Department of Botany and Zoology, Private Bag X1, University of Stellenbosch, \\ Matieland, 7602, South Africa. \\ ${ }^{2}$ Department of Life Sciences, Natural History Museum, London, UK. \\ ${ }^{3}$ Museu de Historia Natural, Travessia de Zambeze, Maputo, Mozambique. \\ ${ }^{4}$ Department of Biological and Medical Sciences, Oxford Brookes University, \\ Oxford, OX3 0BP, UK. \\ "Corresponding author: srd@sun.ac.za \\ 2Email: g.bittencourt@nhm.ac.uk \\ 32Email: neliavanessa91@gmail.com \\ ${ }^{4}$ Email: jlbayliss@yahoo.co.uk

\footnotetext{
${ }^{1}$ urn:1sid:zoobank.org:author:A036B72C-E34E-430F-8F58-7C24B01D0A77

${ }^{2}$ urn:1sid:zoobank.org:author:485CF326-C18E-4A96-A33F-751BB734A304

${ }^{3}$ urn:1sid:zoobank.org:author:438DAA34-14F6-4414-9AB1-293524C8F8EF

${ }^{4}$ urn:lsid:zoobank.org:author:31331836-8992-4B5A-B5D2-01921364BBE6
}

\begin{abstract}
Patterns and processes of cladogenesis among taxa living on the Mozambique 'sky islands' remain poorly studied. During the present study, we report on a new freshwater crab species from Mount Lico, an inselberg and 'sky island' in the Zambezia Province of Mozambique. Phylogenetic analyses using three mitochondrial DNA sequence loci (12S rRNA, 16S rRNA and COI) were used to determine the evolutionary placement of the freshwater crab specimens from Mount Lico. The freshwater crab specimens from Mount Lico were retrieved sister to Potamonautes choloensis. The new species, Potamonautes licoensis sp. nov., is described and compared with other southern African freshwater crab species. Divergence time estimations for the Mozambican freshwater crab species suggest a Miocene/Plio-Pleistocene diversification. Some endemic 'sky island' species form an early branching and are sister to other predominantly East African species, while other 'sky island' species are more recently derived and nested within a predominantly southern African clade. The present study presents the description of the fourth endemic freshwater crab species from Mozambique and suggests that the species diversity in the country is likely highly underrepresented, reiterating the call for renewed systematic surveys. An argument for the conservation of these mountainous 'sky islands' is presented.
\end{abstract}

Keywords. Alpha taxonomy, species diversity, novel lineages, sky island, conservation. 
Daniels S.R., Bittencourt-Silva G.B., Muianga V. \& Bayliss J. 2020. Phylogenetics of the freshwater crab (Potamonautes MacLeay, 1838) fauna from 'sky islands' in Mozambique with the description of a new species (Brachyura: Potamoidea: Potamonautidae). European Journal of Taxonomy 716: 1-23.

https://doi.org/10.5852/ejt.2020.716

\section{Introduction}

The East African Afrotemperate biodiversity hotspot, one of eight on the continent, extends from the Eritrean highlands along the East African coast including Djibouti, Ethiopia, Kenya, Rwanda, Burundi, Uganda, the eastern Democratic Republic of the Congo, Tanzania and Zimbabwe, and terminates in Mozambique (Mittermeier et al. 2004). The region contains three ancient blocks of mountain massif, the Eastern Arc Mountains and Southern Rift, the Albertine Rift and the Ethiopian Highlands, while the volcanic highlands of Kenya and Tanzania are of more recent, early Miocene origin (Davidson \& Rex 1980; Sepulchre et al. 2006). The area is home to an exceptional floral and faunal diversity, contains a large number of charismatic species and includes some of the classic examples of adaptive radiations known in evolutionary biology in the African Great Lakes (Mittermeier et al. 2004). Speciation in the southern mountains of the East African hotspot is poorly studied in comparison to that in the central and northern regions (Assefa et al. 2007; Demos et al. 2014).

Central and northern Mozambique are characterized by several isolated montane inselbergs, often termed 'sky islands'. The 'sky islands' typically occur at high elevations and harbour Afrotemperate forest patches, maintained by orographic rainfall. It is believed that these forests are relict fragments of ancient, once widespread forests. The isolation of the Afrotemperate 'sky islands', presumably over millions of years, has resulted in high levels of diversity and endemism, possibly as a result of allopatric speciation (Kissling et al. 2012). The biogeographic affinities of taxa on the Mozambique 'sky islands', in relation to species in southern and eastern Africa are generally unknown. Phylogenetic studies have been conducted on several vertebrate groups (Taylor et al. 2012; Branch et al. 2014; Conradie et al. 2018), but the invertebrate fauna of the 'sky islands' has to date received limited alpha taxonomic attention and evolutionary relationships remain poorly understood.

One of the invertebrate groups that has undergone intense recent study is the freshwater crab fauna of southern African (Daniels \& Bayliss 2012; Phiri \& Daniels 2013, 2014; Daniels et al. 2014; Daniels 2017; Peer et al. 2017). For example, in South Africa, nine freshwater crab species have been described in the last five years (Potamonautes barbari and P. barnardi both described by Phiri \& Daniels (2014), P. danielsi Peer, Gouws, Lazo-Wasem, Perissinotto \& Miranda, 2017, P. flavusjo Daniels, Phiri \& Bayliss, 2014, P. isimangaliso Peer, Perissinotto, Gouws \& Miranda, 2015, P. ntendekaensis Daniels, Busschau \& Cumberlidge, 2019, P. ngoyensis Daniels, Busschau \& Cumberlidge, 2019, P. mhlophe Daniels, 2017 and P. tuerkayi Wood \& Daniels, 2016). Recently, the first endemic species from Zimbabwe, P. mutareensis Phiri \& Daniels, 2013, was described, while the endemic freshwater crab P. mulanjeensis Daniels \& Bayliss, 2012 was described from Malawi. Similarly, recent biotic surveys of the 'sky islands' in Mozambique led to the discovery of three endemic freshwater crab species: P. bellarussus Daniels, Phiri \& Bayliss, 2014 from Yao Mountains, P. namuliensis Daniels \& Bayliss, 2012 from Mount Namuli and P. gorongosa Cumberlidge, Naskreski \& Daniels, 2016 from Mount Gorongosa. Currently, ten freshwater crab species are known from Mozambique (Cumberlidge et al. 2016). Extrapolating the results for the freshwater crabs to other understudied groups, it would be reasonable to assume that the hitherto described level of biodiversity has been underestimated. For example, recent surveys of the 'sky islands' have resulted in the discovery of several new butterfly species (Congdon et al. 2010; Congdon \& Bayliss 2012; Bayliss et al. 2016, 2018, 2019; van Velzen et al. 2016), five chameleons (Branch \& Tolley 2010; Branch et al. 2014), four mongrel frogs (Conradie et al. 2018), two snakes (Branch \& Bayliss 2009; Branch et al. 2019), a gecko (Portik et al. 2013) and a 
bat (Taylor et al. 2012). Collectively, these results reiterate the renewed call for continuous biodiversity surveys of the neglected 'sky islands' in the interior of Mozambique. Such studies are important to fostering a better understanding of the evolutionary and biogeographic relationships of taxa in the region and aid the conservation management of these species.

A recent expedition, organized and led by the last author, to Mount Lico, an inselberg in the interior of the Zambezia Province of Mozambique, was undertaken to document its biodiversity, since the region has historically been unsampled. Mount Lico is approximately $1100 \mathrm{~m}$ above sea level (a.s.l) and has sheer rock walls of up to $700 \mathrm{~m}$ a.s.1., with old growth rain forest on top of a granite crater, and is uninhabited. The expedition resulted in the collection of a new freshwater crab species, which does not conform to the ten described species from Mozambique. The species occurs on the slope and atop of Mount Lico. In the present study, the new freshwater crab species is compared phylogenetically to the ten known species from Mozambique and described based on morphological and genetic data. In addition, we undertook a divergence time estimation of all of the described mountain-living species from Mozambique in order to understand the mechanism of speciation that are causal to cladogenesis. We compared the divergence time estimations obtained during the present study to those observed in previous studies to understand the phylogenetic relationship of the fauna of the Mozambique 'sky island' region.

\section{Material and methods}

\section{Sample collection}

Twenty-three freshwater crab specimens were collected from under stones by hand or using a dipnet in streams and rivers on the slopes and atop of Mount Lico, in the Zambezia Province, Mozambique. A handheld GPS was used to record the latitude and longitude, and freshwater crabs were preserved in either absolute ethanol or formalin.

\section{DNA extraction, PCR and sequencing}

Muscle tissue extracted from walking legs was subjected to DNA extraction using a Nucleospin kit (Macherey-Nagel, Duren, Germany), following the manufacturer's protocol. Extracted DNA was stored in a refrigerator at $-20^{\circ} \mathrm{C}$ until required for PCR. Generally, a $1 \mu 1$ DNA in $19 \mu 1$ water dilution was performed prior to use. Three partial mtDNA gene fragments were selected for the present study; these included cytochrome oxidase subunit one (COI), 12S rRNA and 16S rRNA. These three loci were selected because each has a different mutational rate and they have been successfully used for reconstructing evolutionary relationships among freshwater crabs (Daniels et al. 2002a, 2002b, 2006, 2015, 2019; Phiri \& Daniels 2013, 2014, 2016; Gouws et al. 2015; Wood \& Daniels 2016; Daniels \& Klaus 2018). Primer pairs are outlined in Daniels et al. (2002b, 2006, 2015). Standard PCR conditions for amplification and DNA sequencing protocols were followed (Daniels et al. 2006, 2015, 2019; Daniels 2017). Sequences for all the described southern African freshwater crab species were downloaded from GenBank for each of the three mitochondrial gene regions and included to understand the phylogenetic placement of the Mozambique freshwater crab species (Daniels \& Bayliss 2012; Daniels et al. 2014, 2019; Phiri \& Daniels 2014; Peer et al. 2015, 2017; Wood \& Daniels 2016; Daniels 2017). We used four species of Liberonautes Bott, 1955 (L. lugbe Cumberlidge, 1999, L. latidactylus (De Man, 1903), L. nimba Cumberlidge, 1999 and L. rubigimanus Cumberlidge \& Sachs, 1989) as outgroups, since the latter genus is sister to Potamonautes (Daniels et al. 2015).

\section{Phylogenetic analyses and divergence time estimation}

Sequence Navigator (Applied Biosystems) was used to compute a consensus sequence from forward and reverse strands for each of the three gene fragments. No insertions or deletions were evident for the protein-coding COI locus and sequences for this locus were aligned manually. The 12S rRNA and 16S rRNA loci were aligned using Clustal X ver. 2.1 (Thompson et al. 1997). Since all three partial 
fragments occur on the mitochondria and are linked, we combined the DNA sequence data for the three fragments into a single data matrix and conducted all analyses on the combined data set. Maximum Likelihood (ML) and Bayesian approaches were used to estimate evolutionary relationships. jModelTest (Posada 2008) was used to obtain the best-fit substitution model for each of the three gene loci (results not shown). These substitution models were used in the partitioned Bayesian analyses. The best-fit substitution models were chosen using the Akaike Information Criteria (AIC) (Akaike 1973), since this reduces the number of parameters that contribute little to describing the data by penalizing more complex models (Nylander et al. 2004; Posada \& Buckley 2004). Maximum likelihood analysis was conducted on the concatenated data set in RAxML ver. 7.2.7 (Stamatakis 2006). The robustness of branches of the best ML tree was assessed with 1000 bootstrap replicates using the CAT algorithm for fast bootstrapping, while the final tree search was conducted under the GTR $+\mathrm{G}$ model for all three partitions as less complicated models are not implemented in RAxML. Bayesian inferences were used to investigate optimal tree space using the program MRBAYES ver. 3.2.6 (Ronquist et al. 2012). For each analysis, four Markov chains were run, with each chain starting from a random tree and run for fifty million generations, sampling each chain every $10000^{\text {th }}$ tree. This process was repeated four times to ensure that trees converged on the same topology using MRBAYES ver. 3.2.6. A 50\% majority rule consensus tree was generated from the trees retained (after the burn-in trees were discarded - using likelihood plots) with posterior probabilities $(\mathrm{p} P)$ for each node estimated by the percentage of time the node was recovered. Posterior probabilities values $<0.95 \mathrm{p} P$ were regarded as poorly resolved (Daniels et al. 2019). Uncorrected 'p' distances were calculated for the COI locus among sister species pairs in PAUP ver. 4.0b10 (Swofford 2002).

To determine the divergence time estimations for the southern African potamonautid crabs, we applied a Yule tree prior and an uncorrelated lognormal relaxed molecular clock after initial test runs (investigating if the standard deviation of the uncorrelated lognormal clock approaches zero), using potamonautid substitution rates (and their standard deviations) as priors that originate from a fossil calibrated phylogeny of the family Potamonautidae Bott, 1970 (Daniels 2011; Daniels et al. 2015; Daniels \& Klaus 2018): $0.81 \%$ per Ma for the rRNA loci $(\mathrm{SD}=0.0013$; linked clock models), $2.85 \%$ per Ma $(\mathrm{SD}=0.005)$ for the COI locus. The maximum clade credibility tree was determined and annotated in TreeAnnotator ver. 2.4.1 (part of the BEAST package) after removal of $10 \%$ of the trees as burn-in.

\section{Morphology}

Preliminary phylogenetic analyses revealed the new species to be sister to $P$. choloensis Chace, 1953. Hence, we included 27 specimens of this species (Daniels \& Bayliss 2012), deposited in the South African Museum of Natural History, Iziko Museums of Cape Town, for morphological comparison (accession numbers SAMC 46802-46807). Freshwater crab specimens of both species were divided into males and females, since freshwater crabs exhibit sexual dimorphism and characters for both females and males can thus be taken. The following measurements were taken with digital callipers: carapace length (CL); the carapace width at widest point $(\mathrm{CWW})$; the width of the posterior margin of the carapace (CWP); the distance between the postfrontal crest and the anterior margin of the carapace (PFCD); the frontal width, measured between the medial margins of the orbits (FW); the distance between the exorbital teeth (CWA); the carapace height $(\mathrm{CH})$; the length and width of the merus of pereiopods 2 and 5 (PML and PMW), the length of the propodus of the major cheliped (MCPL). All measurements are given in millimetres (mm). Samples have been deposited in the South African Museum of Natural History, Iziko Museums of Cape Town (SAMC). The new species from Mount Lico, Mozambique, was photographed in the field and the laboratory with a Canon EOS 6D camera and Canon $100 \mathrm{~mm}$ f2.8 Macro USM lens. The structure of gonopods 1 and 2 for the new species and P. choloensis is compared. In addition, the major and minor cheliped of the new species were photographed with a $31 \mathrm{~mm}$ extension tube to the aforementioned setup to increase magnification. 


\section{Results}

\section{Phylogeny and divergence time estimation}

A total of 1250 base pairs were included in the present phylogenetic analyses and included $600 \mathrm{bp}$, $450 \mathrm{bp}$ and $310 \mathrm{bp}$ fragments for the COI, 16S rRNA and 12S rRNA loci, respectively. The tree topologies from the BI and the ML analysis were nearly identical, hence, only the BI tree topology is shown (Fig. 1). Potamonautes MacLeay, 1838 was monophyletic (1.00 pP/100\%) and comprised three deeply divergent clades. Clade $1(1.00 \mathrm{pP} / 98 \%)$ contained five east African freshwater crab species, all occurring in Mozambique (but not all endemic to the country); the endemic $P$. namuliensis, sister to P. obsesus A. Milne-Edwards, 1868, in turn sister to a clade containing $P$. calcaratus Gordon, 1929 as sister to $P$. choloensis Chace, 1953 and P. licoensis sp. nov.

Clade $2(<95 \mathrm{pP} / 100 \%)$, comprised species exclusive to southern Africa. Within the latter clade, the two small-bodied, mountain-living species from the Drakensberg Mountain (P. clarus Gouws, Stewart \& Coke, 2000 sister to $P$. depressus Krauss, 1843) were sister to the four Cape Fold Mountain (P. parvispina Stewart, 1997 sister to P. parvicorpus Daniels, Stewart \& Burmeister, 2001, sister to P. tuerkayi and $P$. brincki Bott, 1960). The following clade $(1.00 \mathrm{p} P / 100 \%)$ contains the three Indian Ocean Coastal Belt forest-dwelling species (P. danielsi Peer, Gouws, Lazo-Wasem, Perissinotto \& Miranda, 2017 sister to $P$. isimangaliso sister to P. lividus Gouws, Stewart \& Reavell, 2001) and was sister to a clade of large-bodied riverine species (1.00 pP/95\%) (P. sidneyi Rathbun, 1904 basal sister to P. barnardi, P. barbarai, P. perlatus H. Milne Edwards, 1837, P. granularis Daniels, Stewart \& Gibbons, 1998, with the latter clade being sister to three riverine species characterized by dentition on the anterolateral carapace margin $(1.00 \mathrm{p} P / 77 \%)$ that included $P$. warreni Calman, 1918 sister to P. unispinus Stewart \& Cook, 1998 sister to P. bayonianus Brito-Capello, 1864). The next clade contained most of the recently described freshwater crab species, with $P$. mhlophe sister to P. dentatus Stewart, Cook \& Coke, 1995 forming a clade sister to the mountain-living species $(1.00 \mathrm{p} P / 83 \%), P$. gorongosa sister to P. mutareensis sister to P. mulanjeensis, while P. flavusjo was sister to P. ntendekaensis and P. ngoyensis.

Clade 3 comprised eight East African freshwater crab species with P. platynotus Cunnington, 1907 sister to P. raybouldi Cumberlidge \& Vannini, 2004 in turn sister to a clade comprised of P. lirrangensis Rathbun, 1904 sister to P. suprasulcatus Hilgendorf, 1898. The next clade contained P. niloticus H. Milne Edwards, 1837 sister to P. subukia Cumberlidge \& Dobson, 2008 and P. odhneri Colosi, 1924, and the latter two species were sister to P. bellarussus.

Using the COI locus, the sister species, $P$. choloensis and P. licoensis sp. nov. had an uncorrected ' $p$ ' sequence distance of $8.67 \%$. The latter value is comparable to the uncorrected ' $p$ ' distances that have been reported for sister species. For example, the uncorrected sequence 'p' distances between P. dentatus and P. mhlophe was $10.89 \%$, while between P. ngoyensis and P. ntendekaensis the uncorrected 'p' distance was $8.10 \%$. Similarly, between the Indian Ocean Coastal Belt sister species, $P$. lividus and P. isimangaliso the COI uncorrected ' $\mathrm{p}$ ' distance was $7.90 \%$, while the uncorrected ' $\mathrm{p}$ ' distance between these species and $P$. danielsi was $8.67 \%$. The uncorrected sequence distance between P. licoensis sp. nov. and its sister species, together with its morphological distinction from $P$. choloensis leads us to recognize it as a distinct species.

Divergence of the monophyletic Potamonautes sampled in the present study occurred $10.73 \mathrm{Ma}$ [95\% HPD 8.23-13.43 Ma] (Fig. 1). Divergence in clade 1, containing only east African species was initiated 7.58 Ma [95\% HPD 5.28-10.09 Ma]. The divergence of P. licoensis sp. nov. from its sister species P. choloensis occurred 2.49 Ma [95\% HPD 1.43-3.46 Ma]. The divergence of the latter clade from 
P. calcaratus occurred $6.05 \mathrm{Ma}$ [95\% HPD 3.87-8.27 Ma]. The divergence between $P$. namulieensis and P. obesus occurred 5.41 Ma [95\% HPD 3.33-7.63 Ma]. Clades 2 and 3 diverged $9.03 \mathrm{Ma}$ [95\% HPD 7.02-11.23 Ma]. Within clade 2, containing southern African species, divergence was initiated $7.07 \mathrm{Ma}$ [95\% HPD 5.42-8.79 Ma]. The divergence of the predominantly mountain-living species occurred $5.08 \mathrm{Ma}$ [95\% HPD 3.44-6.88 Ma]. The divergence of the predominantly river-living species occurred $5.26 \mathrm{Ma}$ [95\% HPD 4.07-6.49 Ma]. Within clade 3, containing a second group of east African species divergence occurred $8.00 \mathrm{Ma}$ [95\% HPD 6.09-10.04 Ma] within this clade P. bellarussus diverged from its two closest sampled sister species, 6.12 Ma [95\% HPD 4.34-7.99 Ma].

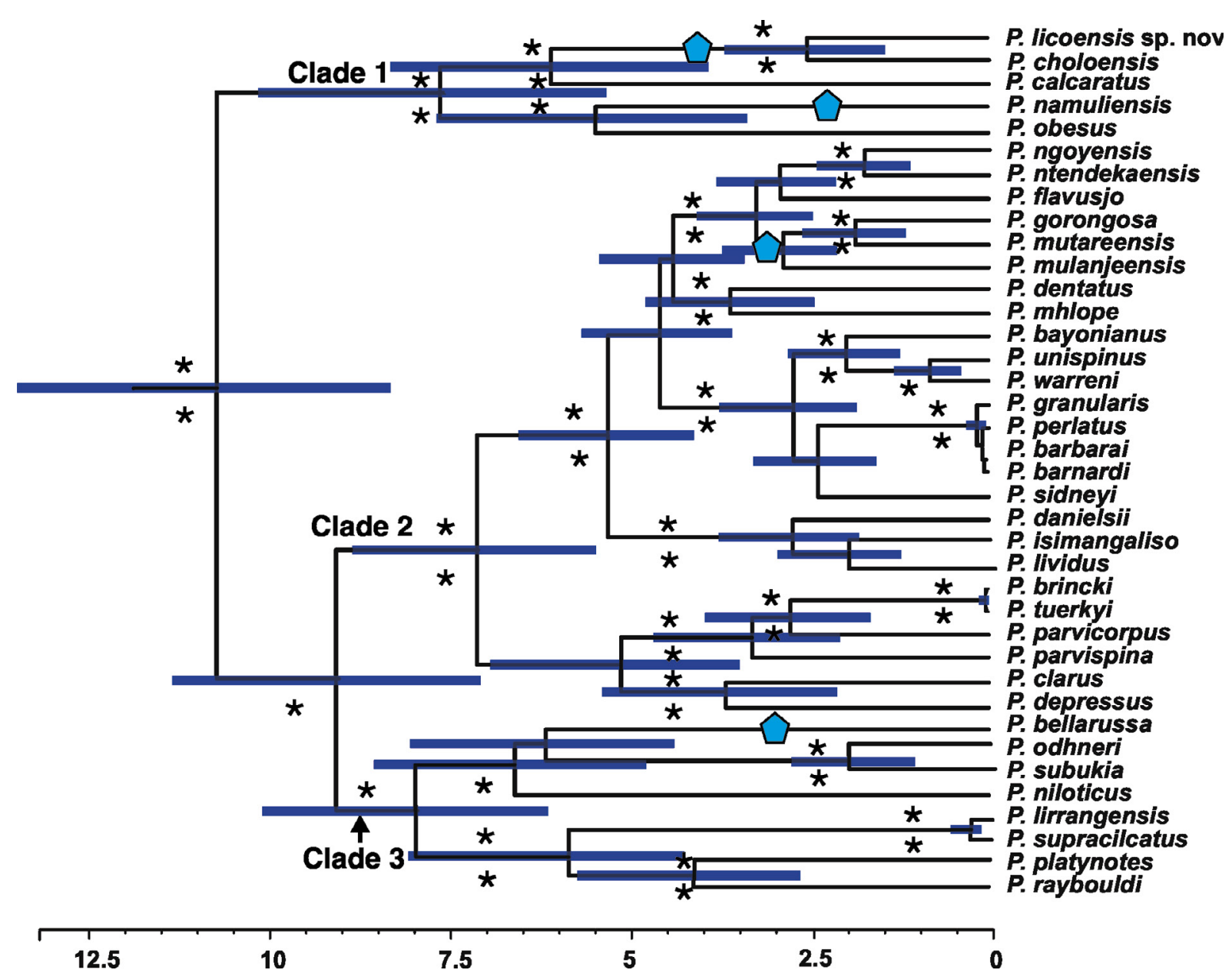

Fig. 1. A Bayesian Inference phylogram and divergence time estimation for the three mtDNA loci (12S rRNA + 16S rRNA + COI) for the eastern and southern African freshwater crab genus Potamonautes MacLeay, 1838, with outgroups removed. Bootstrap values $>75 \%$ are indicated below each node while posterior probability values $>0.95 \mathrm{p} P$ are shown above each node by an asterisk $(*)$. Where no asterisk is present no support for a node was obtained. Blue polygons on branches indicates species present, on Mozambique 'sky islands'. 


\section{Infraorder Brachyura Latreille, 1802 \\ Superfamily Potamoidea Ortmann, 1896 \\ Family Potamonautidae Bott, 1970 \\ Subfamily Potamonautinae Bott, 1970 \\ Genus Potamonautes MacLeay, 1838}

Potamonautes licoensis sp. nov. urn:Isid:zoobank.org:act:0DCF9EC6-858E-4E0F-BFFA-CE17095DCCE7

Figs 1, 2A-C, 3A-D, 4A-B, 5A-B, 8; Table 1

\section{Diagnosis}

Carapace: highly flat $(\mathrm{CH} / \mathrm{CL}=0.44)$ (Table 1$)$; postfrontal crest well-defined, complete, lateral ends meeting anterolateral margins; epigastric crests faint, median sulcus between crests short, not forked posteriorly; exorbital, epibranchial teeth reduced to granules; anterolateral carapace margin with small tooth epibranchial (Figs 2A-C, 5A). Third maxilliped: ischium with distinct vertical sulcus (Fig. 3C); s3/s4 complete, V-shaped, deep, midpoint almost meeting anterior margin of sterno-pleonal cavity; margins of s4 low, not raised (Fig. 2B). Cheliped: dactylus (moveable finger) slim, highly arched, enclosing oval interspace, with three larger teeth interspersed by smaller teeth along length; propodus (fixed finger) with four larger teeth interspersed by smaller teeth along length (Fig. 2A-C); carpus inner margin distal tooth large, pointed, proximal tooth reduced to granules (Fig. 3A); medial inferior margin of merus lined with series of small granules terminating distally at small, low distal meral tooth, lateral inferior margin smooth. G1 terminal article: $1 / 3^{\mathrm{rd}}$ length of subterminal segment; first third straight in line with longitudinal axis of subterminal segment, middle part directed outward at $45^{\circ}$, widened by raised rounded ventral lobe, tip curving sharply upward (Fig. 3A-B).

\section{Etymology}

Named for Mount Lico, from where the species was first collected.

\section{Material examined}

Holotype

MOZAMBIQUE • $\sigma^{\wedge}$ adult; Zambezia Province, top of Mount Lico; $-15.79196^{\circ}$ S, $37.36057^{\circ}$ E; 900 m a.s.1.; 9 Sep. 2019; Julian Bayliss leg.; forest streams; SAM C-A091399.

\section{Paratype}

MOZAMBIQUE • $\widehat{\jmath}$ adult; Zambezia Province, top of Mount Lico; 5 May 2018; Julian Bayliss leg.; SAM C-A091400.

\section{Other material examined}

MOZAMBIQUE - Zambezia Province -2 $q$ adults, 1 adult, 4 juvs; top of Mount Lico; 10 Sep. 2019; Julian Bayliss leg.; forest streams; SAM C-A091401 • 1 त adult, 1 q adult, 1 juv.; Mount Lico; 16 May 2018; Julian Bayliss leg.; SAM C-A091402 • 1 đ adult, 5 juvs; Mount Lico base stream; 9 Sep. 2019; Gabriella Bittencourt-Silva leg.; SAM C-A091402; 2 우 adults, 3 juvs; Mount Lico base stream; 16 May 2018; Vanessa Muianga leg.; SAM C-A091403.

\section{Description}

Based on male holotype (CWW $22.89 \mathrm{~mm}$, Table 1). Carapace with small distinct tooth on the anteriolateral margins; widest anteriorly, narrowest posteriorly (CWP/CL 0.60); flattened (CH/CL 0.43) (Fig. 2A); front broad, $1 / 3 \mathrm{CWW}$ (FW/CWW 0.37); urogastric, cardiac grooves distinct, other grooves faint or missing; postfrontal crest complete, anterolateral margin posterior to epibranchial tooth granulated, meeting epibranchial teeth; epigastric crests faint, median sulcus between crests short, forked 
Table 1. Potamonautes licoensis sp. nov., measurements (in $\mathrm{mm}$ ) of the holotype and of additional male and female specimens examined, presented as a range.

\begin{tabular}{lcccc}
\hline Variable & Abbreviation & Holotype & Males & Females \\
\hline carapace length & $\mathrm{CL}$ & 17.55 & $19.91-13.13$ & $16.62-12.29$ \\
carapace width at widest point & $\mathrm{CWW}$ & 22.89 & $20.91-16.56$ & $20.01-15.76$ \\
carapace posterior margin & $\mathrm{CWP}$ & 10.66 & $11.01-8.34$ & $10.71-7.98$ \\
frontal width & $\mathrm{FW}$ & 8.60 & $8.10-8.33$ & $8.17-5.44$ \\
distance between postfrontal crest & $\mathrm{PFCD}$ & 2.74 & $2.48-2.34$ & $2.64-2.06$ \\
and anterior margin & & & & \\
carapace height & $\mathrm{CH}$ & 7.75 & $7.66-6.05$ & $7.61-5.84$ \\
major cheliped propodus length & $\mathrm{MCPL}$ & 22.59 & $11.55-8.72$ & $11.79-8.72$ \\
pereiopod 2, merus length & $\mathrm{P} 2 \mathrm{ML}$ & 9.88 & $8.53-7.06$ & $8.15-7.14$ \\
pereiopod 2, merus width & $\mathrm{P} 2 \mathrm{MW}$ & 3.61 & $3.41-2.74$ & $2.67-2.56$ \\
pereiopod 5, merus length & $\mathrm{P} 5 \mathrm{ML}$ & 9.36 & $9.01-7.79$ & $10.09-7.29$ \\
pereiopod 5, merus width & $\mathrm{P} 5 \mathrm{MW}$ & 3.07 & $3.81-3.01$ & $2.79-3.10$ \\
\hline
\end{tabular}

posteriorly; exorbital, epibranchial teeth each reduced to granule; anterolateral margin between exorbital, epibranchial teeth faintly granulated, curving slightly outward, lacking intermediate tooth; (Fig. 2B-C) branchiostegal wall vertical sulcus faint, meeting longitudinal sulcus, dividing branchiostegal wall into 3 parts, suborbital, dorsal pterygostomial regions granulated, hepatic region smooth; suborbital margin faintly granulated. Third maxilliped: filling entire buccal frame, except for respiratory openings; exopod with long flagellum, ischium with faint vertical groove (Fig. 4A). Epistomial tooth large, triangular, margins lined by large granules. Mandible: palp two-segmented; terminal segment simple; tuft of setae at junction between segments. Sternum: s1, s2 fused; s2/s3 deep, completely crossing sternum; s3/s4 complete, V-shaped, deep, midpoint almost meeting anterior margin of sterno-pleonal cavity; margins of s4 low, not raised. Cheliped: dactylus (moveable finger) slim, arched, enclosing oval interspace, with three larger teeth interspersed by smaller teeth along length; propodus (fixed finger) with four larger teeth interspersed by smaller teeth along length (Fig. 4A-B); carpus distal tooth large, pointed, proximal tooth small but distinct, followed by granule; both inferior margins of merus lined by series of small granules, distal meral tooth small, pointed. Pereopods: walking legs slender, pereopod 3 longest, pereopod 5 shortest; dorsal margins of pereopods with fine sharp bristles, dactyli of walking legs ending in sharp point, with rows of spine-like bristles along segment. Pleon: outline broadly triangular with straight margins. G1 terminal article: short ( $1 / 3^{\text {rd }}$ length of subterminal segment), curving away from midline, first third straight in line with longitudinal axis of subterminal segment, middle part directed outward at $45^{\circ}$, widened by low raised rounded ventral lobe, tip curving gently upward. G1 subterminal segment broad at base, tapering to slim junction with terminal article distally where these two parts have same width, ventral side of segment with heavily setose margins; with setae-fringed flap covering lateral half of segment; dorsal side of segment smooth, no flap, with broad membrane on the dorsal side of suture marking junction between terminal, subterminal parts (Fig. 3A-B). G2: terminal article long, flagellum-like, 0.5 times as long as of subterminal segment (Fig. 3C-D). 

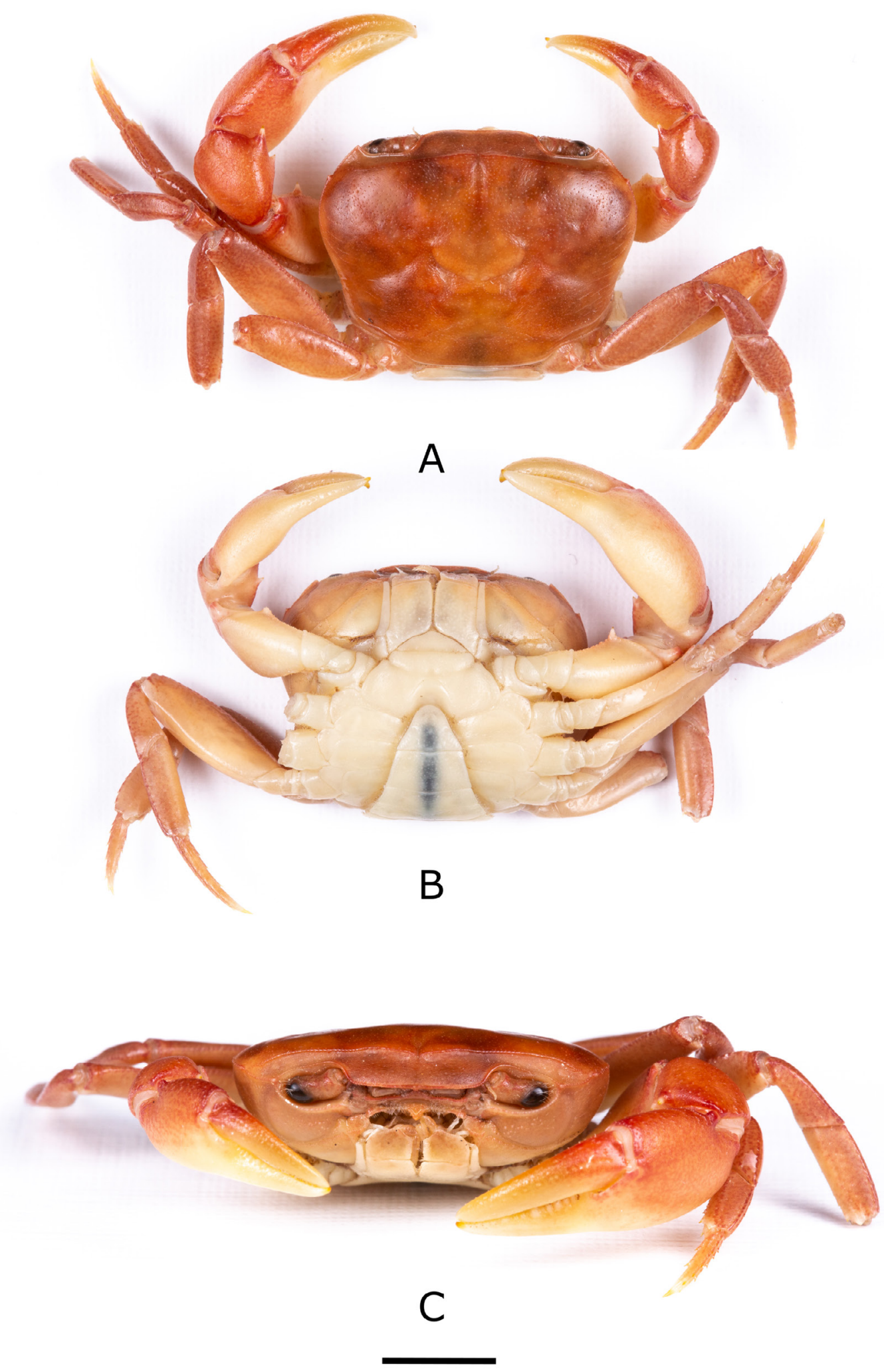

Fig. 2. Potamonautes licoensis sp. nov., holotype, $\widehat{\partial}(\mathrm{CL}=17.55 \mathrm{~mm})$ (SAM C-A091399). A. Entire animal, dorsal aspect. B. Entire animal, ventral aspect. C. Cephalothorax, frontal aspect. Scale bar $=$ $10 \mathrm{~mm}$. 




Fig. 3. Potamonautes licoensis sp. nov., holotype, ठ̊ (SAM C-A091399). A. Left gonopod 1, anterior view. B. Left gonopod 1, posterior view. C. Left gonopod 2, anterior view. D. Left gonopod 2, posterior view. Scale bar $=10 \mathrm{~mm}$. 


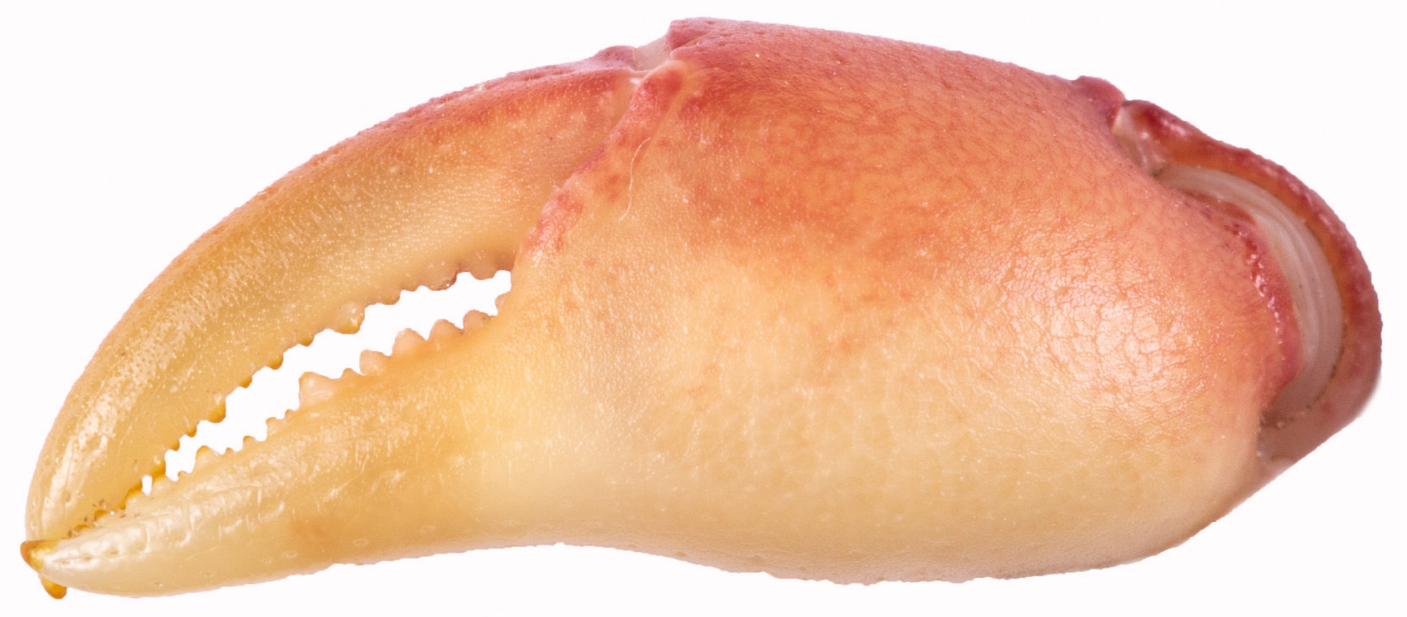

A

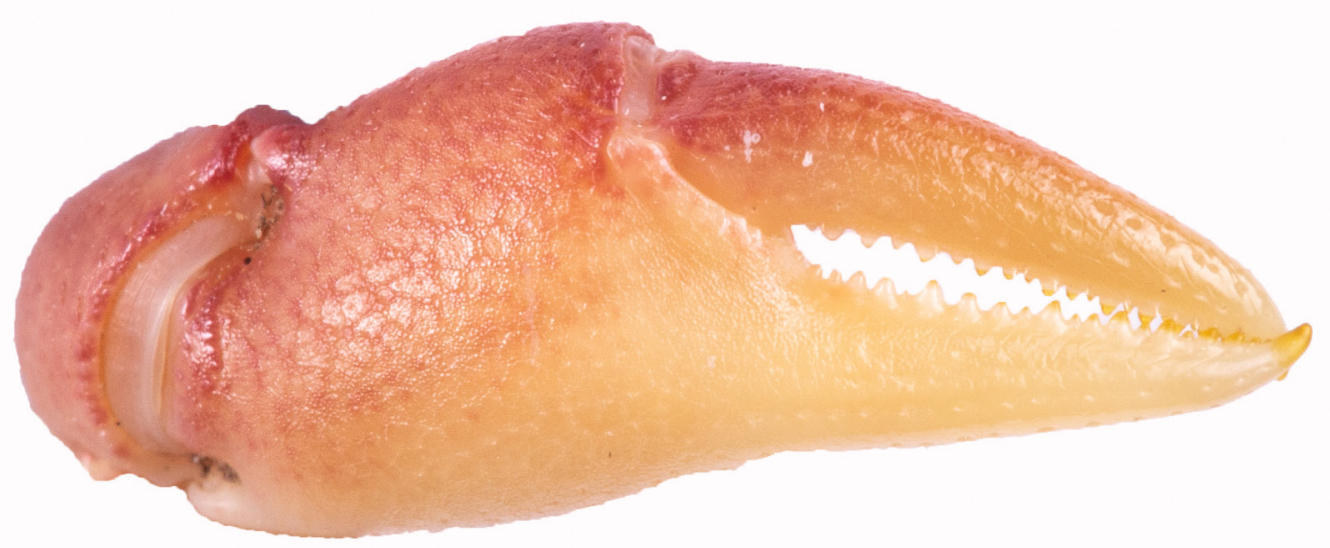

B

Fig. 4. Potamonautes licoensis sp. nov., holotype, ô (SAM C-A091399). A. Major right cheliped. B. Minor left cheliped. Scale bar $=10 \mathrm{~mm}$. 


\section{Size}

A small-bodied species $(\mathrm{CL}=17.55 \mathrm{~mm}$; $\mathrm{CWW}=22.89 \mathrm{~mm})$ (Table 1), typical of mountain stream living freshwater crabs.

\section{Colour in life}

Carapace dark to light brown in living specimens (Fig. 5B).

\section{Type locality}

Mount Lico, Zambezia Province, Mozambique.

\section{Habitat}

Primary rain forest streams on top of Mount Lico, Zambezia Province, Mozambique. Frequently found under small stones in first order streams (Fig. 5A).

\section{Distribution}

Known from Mount Lico, Zambezia Province, Mozambique. More recently, the species has also been collected from Mount Nallume (Daniels pers. obs.).

\section{Remarks}

Phylogenetically, P. licoensis sp. nov. was retrieved as sister to P. choloensis (Fig. 1). Both species are characterized by a small but prominent epibranchial tooth on the anterolateral margins of the carapace and a arched right dactylus. However, the two species can easily be distinguished morphologically. Potamonautes choloensis is a large-bodied species ( $\mathrm{CL}>42.00 \mathrm{~mm}$ ) (Fig. 6A-C; Table 2), with a swollen carapace $(\mathrm{CH} / \mathrm{CL}=0.50)$, while $P$. licoensis $\mathrm{sp}$. nov. is small-bodied $(\mathrm{CL}>20.00 \mathrm{~mm})$ and has a more flat carapace $(\mathrm{CH} / \mathrm{CL}=0.44)$. Potamonautes licoensis $\mathrm{sp}$. nov. shows adaptations to living under stones in fast flowing mountain streams. Gonopods 1 and 2 of $P$. choloensis and P. licoensis sp. nov. are different in appearance. Gonopod 1 is nearly straight (Fig. 7A-B) in P. choloensis, while arching in P. licoensis sp. nov. (Fig. 3A-B). The terminal segment of gonopod 2 is filamentous in both species, however, in P. choloensis it is less curved (Fig. 7C) while it exhibits a significant curvature in P. licoensis sp. nov. (Fig. 3C-D). Furthermore, the two species are characterized by an uncorrected ' $\mathrm{p}$ ' distance for the COI locus similar to what has been recorded in other sister species pairs (Daniels \& Bayliss, 2012; Daniels 2017; Daniels et al. 2019). Similarly, Gouws et al. (2015) found deep genetic divergence, ranging from 9.20 to $11.80 \%$ between lineages within $P$. sidneyi, leading to the recognition of $P$. danielsi. In addition, $P$. choloensis and $P$. licoensis sp. nov. are ecologically distinct. While both species are associated with forest streams at high altitude, Potamonautes choloensis is known to occur between 1000-2000 m a.s.l. and has been collected from Mounts Inago, Mulanje, Mabu, Cholo, the Zomba Plateau and more recently from Mount Socone (Fig. 8). The species is present in both Malawi and Mozambique (Daniels unpubl. data; Bayliss pers. com.; Chace 1953; Daniels \& Bayliss 2012). Potamonautes licoensis sp. nov. is known from a maximum of 700-900 m a.s.l. and is present on Mounts Lico and Nallume, and is endemic to Mozambique. More extensive sampling is required to confirm the distribution of $P$. licoensis sp. nov.

Superficially, $P$. licoensis sp. nov. resembles two other freshwater crab species that are also present in Mozambique, to whom it is phylogenetically related (Fig. 1; clade 1). Potamonautes obsesus and P. calcaratus both have a single small, near spine-like tooth on the anterolateral margin of the carapace. However, both of the latter species are large-bodied and characterized by near swollen carapaces, chelipeds and gonopods, morphologically distinct from P. licoensis sp. nov. (Reed \& Cumberlidge 2004). In addition, P. obesus and P. calcaratus are both burrowing, semi-terrestrial species, and live in ephemeral pans in low-lying areas, where they dig into soft soil to locate the water table during the dry 

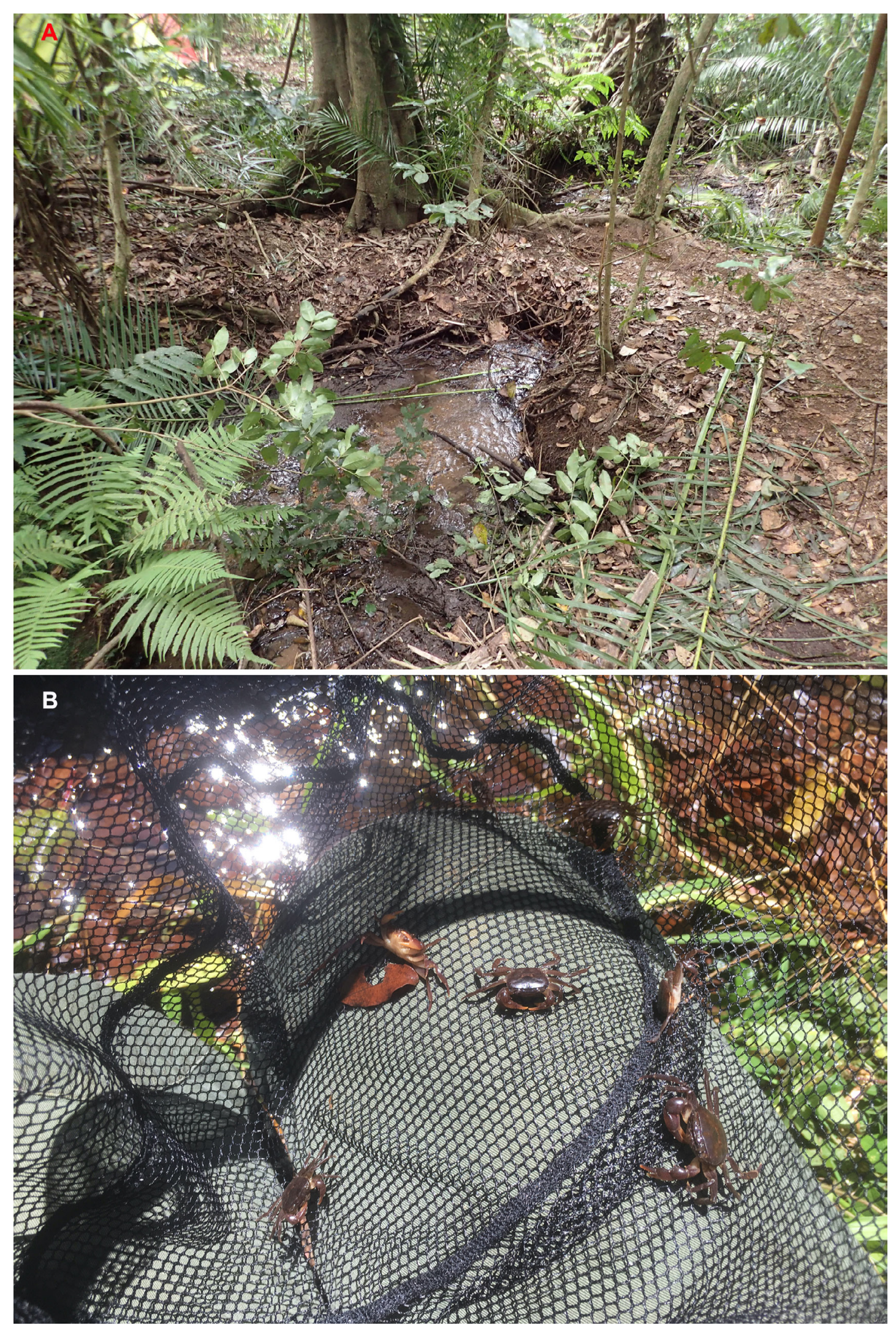

Fig. 5. A. Primary rainforest habitat where Potamonautes licoensis sp. nov. occurs. B. Live colour of P. licoensis sp. nov upon collection. Photographs by J. Bayliss. 


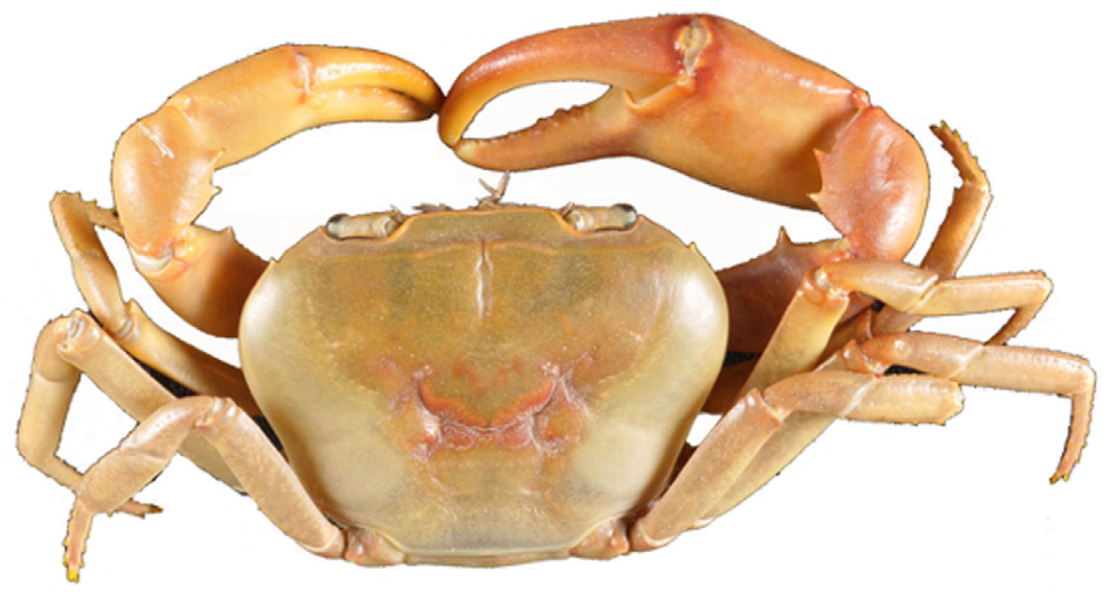

A

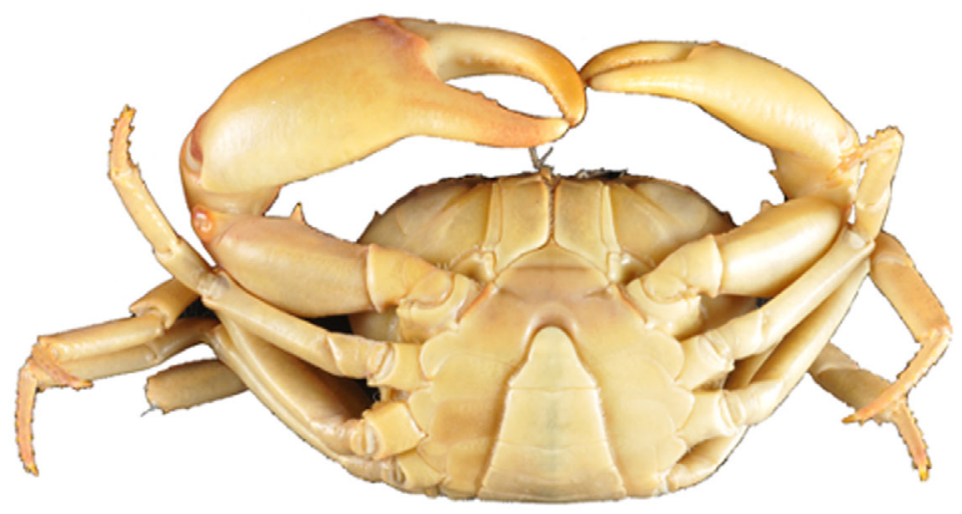

B

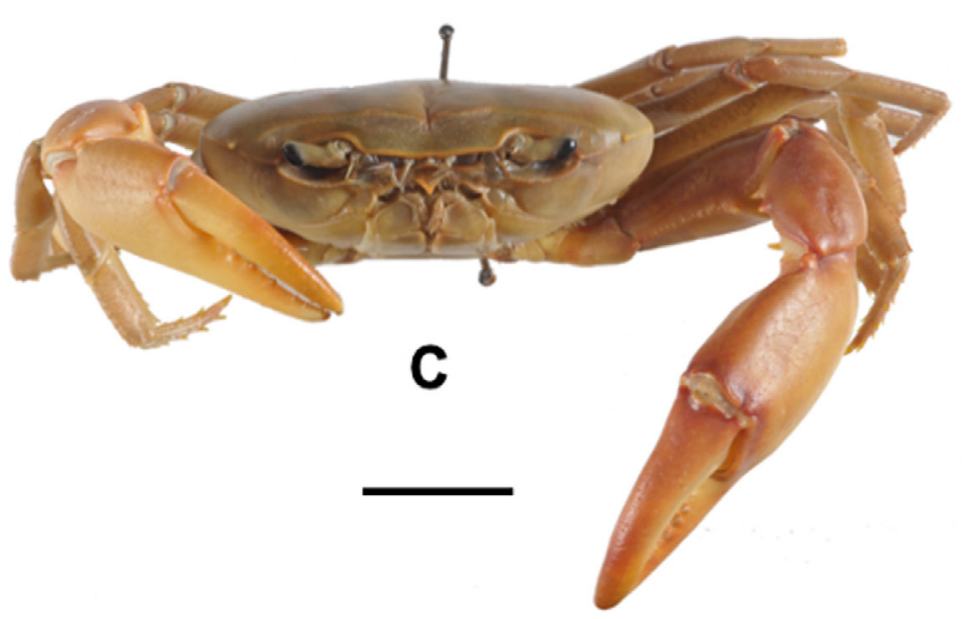

Fig. 6. Potamonautes choloensis Chace, 1953 (SAM A46802). A. Entire animal, dorsal aspect. B. Entire animal, ventral aspect. C. Cephalothorax, frontal aspect. Scale bar $=10 \mathrm{~mm}$. 




Fig. 7. Potamonautes choloensis Chace, 1953 (SAM A46802). A. Left gonopod 1, anterior view. B. Left gonopod 1, posterior view. C. Left gonopod 2, anterior view. Scale bar $=10 \mathrm{~mm}$. 
Table 2. Potamonautes choloensis Chace, 1953 measurements (in $\mathrm{mm}$ ) of the 27 specimens deposited in the South African Natural History Iziko Museum, Cape Town, South Africa.

\begin{tabular}{lccc}
\hline Variable & Abbreviation & Males & Females \\
\hline carapace length & CL & $39.79-24.67$ & $41.53-15.79$ \\
carapace width at widest point & CWW & $54.81-33.16$ & $55.95-21.13$ \\
carapace posterior margin & CWP & $19.45-13.69$ & $24.42-8.77$ \\
frontal width & FW & $18.53-11.64$ & $19.09-7.67$ \\
$\begin{array}{l}\text { distance between postfrontal crest and } \\
\text { anterior margin }\end{array}$ & PFCD & $5.55-3.33$ & $5.03-2.20$ \\
carapace height & CH & $19.78-11.84$ & $19.04-7.27$ \\
major cheliped propodus length & MCPL & $57.01-14.09$ & $39.98-12.14$ \\
pereiopod 2, merus length & P2ML & $24.10-13.92$ & $22.83-8.67$ \\
pereiopod 2, merus width & P2MW & $6.39-4.65$ & $7.11-3.10$ \\
pereiopod 5, merus length & P5ML & $20.72-13.51$ & $21.46-9.50$ \\
pereiopod 5, merus width & P5MW & $6.42-4.55$ & $6.78-3.36$ \\
\hline
\end{tabular}

season (Daniels et al. 2002a; Reed \& Cumberlidge 2004). Both species are widespread; P. calcaratus is present in northeastern South Africa and into Mozambique, while $P$. obsesus is present in Somalia, Kenya, Tanzania, Malawi, Mozambique and Zimbabwe (Reed \& Cumberlidge 2004). Both species show deep genetic differentiation, a pattern typical of burrowing species, and both might potentially represent a species complex (Daniels \& Bayliss 2012). Potamonautes licoensis sp. nov., in contrast, lives at high altitude in rain forest streams. Potamonautes namuliensis, endemic to Mount Namuli in Mozambique, has a smooth anterolateral margin with an arched dactylus of the major pereopod and can easily be differentiated from P. licoensis sp. nov. Potamonautes montivagus (Chace 1953) and P. bellarussus are both large bodied species with $\mathrm{CL}>43.8 \mathrm{~mm}$ and $39.29 \mathrm{~mm}$, respectively, and lack dentition on the anterolateral carapace margins (Chace 1953; Daniels et al. 2014). In P. montivagus the terminal segment of gonopod 1 is at a $90^{\circ}$ angle, very distinct from both $P$. bellarussus and $P$. licoensis sp. nov. Potamonautes montivagus is distributed in Malawi where it is present on Mounts Cholo, Mulanje (formerly spelled Mlanje), Chiradzulu, Ntchisi, Zomba Plateau and Dedza (Chace 1953). Potamonautes bellarussus is only known from two localities, Mounts Mecula and Yao in the Niassa Province of Mozambique, although specimens have recently been collected from neighbouring Malawi and Tanzania (Daniels et al. 2014; N. Cumberlidge and M. Genner pers. com.). Potamonautes sidneyi is present in Mozambique and widespread in southern Africa. It is a large bodied species mainly found in rivers and lacks dentition on the anterolateral carapace margin (Peer et al.2017). Phylogenetically, P. sidneyi is not closely related to P. licoensis sp. nov., (Fig. 1; clade 2). Potamonautes sidneyi is a species complex and comprises several genetically distinct lineages and is in need of a taxonomic revision (Gouws et al. 2015). Potamonautes bayonianus is present in Mozambique, however, it is a large-bodied riverine species, with a sharp and prominent tooth on the anterolateral carapace margin and distantly related to P. licoensis sp. nov. Finally, $P$. gorongosa, endemic to Mozambique, is phylogenetically and morphologically distinct from P. licoensis sp. nov. The former species lacks a dentition on the anterolateral carapace margin and does not have the highly-arched dactylus (Fig. 1; clade 2) of P. licoensis sp. nov. (Fig. 1; clade 1). Potamonautes licoensis sp. nov. bears a superficial resemblance to P. parvispina (Stewart 1997). The latter species is also mountain-living, has a small tooth on the anterolateral carapace margins and a 
highly-arched right dactylus. However, P. parvispina is endemic to the Cederberg Mountains in the Western Cape Province, South Africa, and is phylogenetically distantly related to P. licoensis sp. nov. (Fig. 1; clade 2). All the remaining South African mountain-living freshwater crab species (P. clarus, $P$. depressus, $P$. brincki, $P$. parvicorpus and $P$. tuerkayi) lack dentition on the anterolateral carapace margin and are phylogenetically distinct from $P$. licoensis sp. nov.

\section{Discussion}

Our results clearly demonstrate the presence of a new freshwater crab species from Mount Lico, from the Zambezia Province in Mozambique. These results affirm the call for renewed sampling of the interior of Mozambique, which contains several unsampled mountain areas (Fig. 8). Our phylogenetic tree (Fig. 1) indicates that the five 'sky island' species are distributed between the three major clades and have a tendency to be narrow endemic species, with the exception of $P$. choloensis that is more widespread. In clade 1, divergence in the basal 'sky island' lineage was initiated during the Miocene. However, the divergence between P. licoensis sp. nov. and its sister species, P. choloensis (present on several 'sky islands', Fig. 8), occurred more recently at the onset of the Pleistocene, while the divergence between $P$. namuliensis, a 'sky island' endemic from Mount Namuli, and P. obsesus occurred at the end of the Miocene (Fig. 1). In clade 2, the divergence of P. mulanjeensis, from Mount Mulanje, from its sister species occurred at the end of the Pliocene. In the latter clade, most of the species are the products of a Plio-Pleistocene divergence. Finally, in clade 3, the divergence of P. bellarussus, present on Mounts Mecula and Yao, from its east African sister species occurred at the end of the Miocene. The fact that these clades are distantly related suggests biogeographical influences at different time periods and from different aspects. The lack of monophyly of the 'sky island' freshwater crab fauna, and its distribution across three clades suggests that the divergence among the freshwater crab fauna from these 'sky islands' has occurred at various time intervals during the Mio/Plio-Pleistocene periods. While clade 1 is exclusive to Mozambique, clade 2 has species that predominantly occur in South Africa. In clade 3, P. bellarussus is the only Mozambican 'sky-island' species present in a largely East African clade that occurs further north, predominantly in Tanzania where it has also recently been recorded (N. Cumberlidge and M. Genner pers. com.), suggesting that there is a biogeographical divide between these mountains and those further south, which host species from clades 1 and 2. This supports the theory that these mountains are biogeographically distinct and may represent a distinct ecoregion, as suggested by Bayliss et al. (2014). These results suggest that the diversification and colonization history of freshwater crabs in the region is biogeographically complex. The question now arises is what possible abiotic factors drove the observed cladogenesis among freshwater crabs on the high-altitude mountains of this region of Africa ('sky islands').

Our dated phylogeny indicates both ancient Miocene and a more recent Plio-Pleistocene diversification for the freshwater crabs from the 'sky islands' (Fig. 1). The Miocene consisted of several short term, wet-dry cycles, with a general trend towards an increase in aridification. This resulted in the contraction of lowland forest, the establishment of open grassy landscapes and the general restriction of forested regions to high altitude mountains with sustained precipitation (Rose et al. 2016). The timescale of the cladogenesis suggests that certain ancient, palaeoendemic lineages, such as $P$. namuliensis and $P$. bellarussus, were retained within refugial areas, while others, such as $P$. licoensis and $P$. choloensis, underwent a more recent diversification within refugia and likely reflect Plio-Pleistocene climatic shifts. The refugial areas likely represent areas of climatic and habitat stability for species and might be a pattern that persists across several taxa. However, the extent of this is unknown in the absence of dated phylogenetic studies for other 'sky island' taxa. There is considerable evidence for progressive vegetation shifts from $\mathrm{C}_{3}$ to $\mathrm{C}_{4}$ plants in the East Africa Biodiversity hotspot (Bonnefille 2010; Uno et al. 2016). The vegetation shifts can be associated with increased aridity and the progressive rifting and tectonic uplift in East Africa (deMenocal 2004), a result that is also supported by climatic modelling (Uno et al. 2016). 
Several of these episodes of increased aridification and vegetation shifts appear to be very localized, making it difficult to extrapolate this scenario to the broader East African Rift Valley system, and its general applicability to the 'sky islands' is limited by the lack of climatic modelling and palynological studies in these areas (deMenocal 2004). The phylogenetic studies conducted on the recently described 'sky island' fauna lack divergence time estimations, rendering direct comparison of cladogenic drivers difficult (Branch et al. 2014, 2019). In this respect, multitaxon sampling across a broad spectrum of taxa is needed to properly understand factors causal to the observed pattern. However, in neighbouring South Africa, several animal taxa are thought to have diversified during the Miocene/Plio-Pleistocene epochs as a consequence of shifts in climatic regime and their impact on vegetation, as can be observed in, e.g., tortoises (Hofmeyr et al. 2017), chameleons (Tolley et al. 2008), a forest dwelling gecko (Busschau et al. 2019), frogs (Nielsen et al. 2018) and velvet worms (Barnes et al. 2020).

Several of the novel 'sky island' species are confined to very small patches of pristine forest habitat, suggesting that species need formal conservation assessment. Most of the 'sky island' freshwater crab species are narrow endemics, making them susceptible to extinction, suggesting that a conservation management plan should be developed to conserve the biodiversity of these 'sky islands'. In the interior of Mozambique there are several areas that remain unsampled. These include, for example, Mounts Chiperone, Ribáuè and Njessi - future surveys of freshwater systems should focus on these regions and are likely to reveal additional alpha taxonomic diversity for a number of poorly sampled animal groups. For example, we are aware of at least two, as yet undescribed freshwater crab species, that require

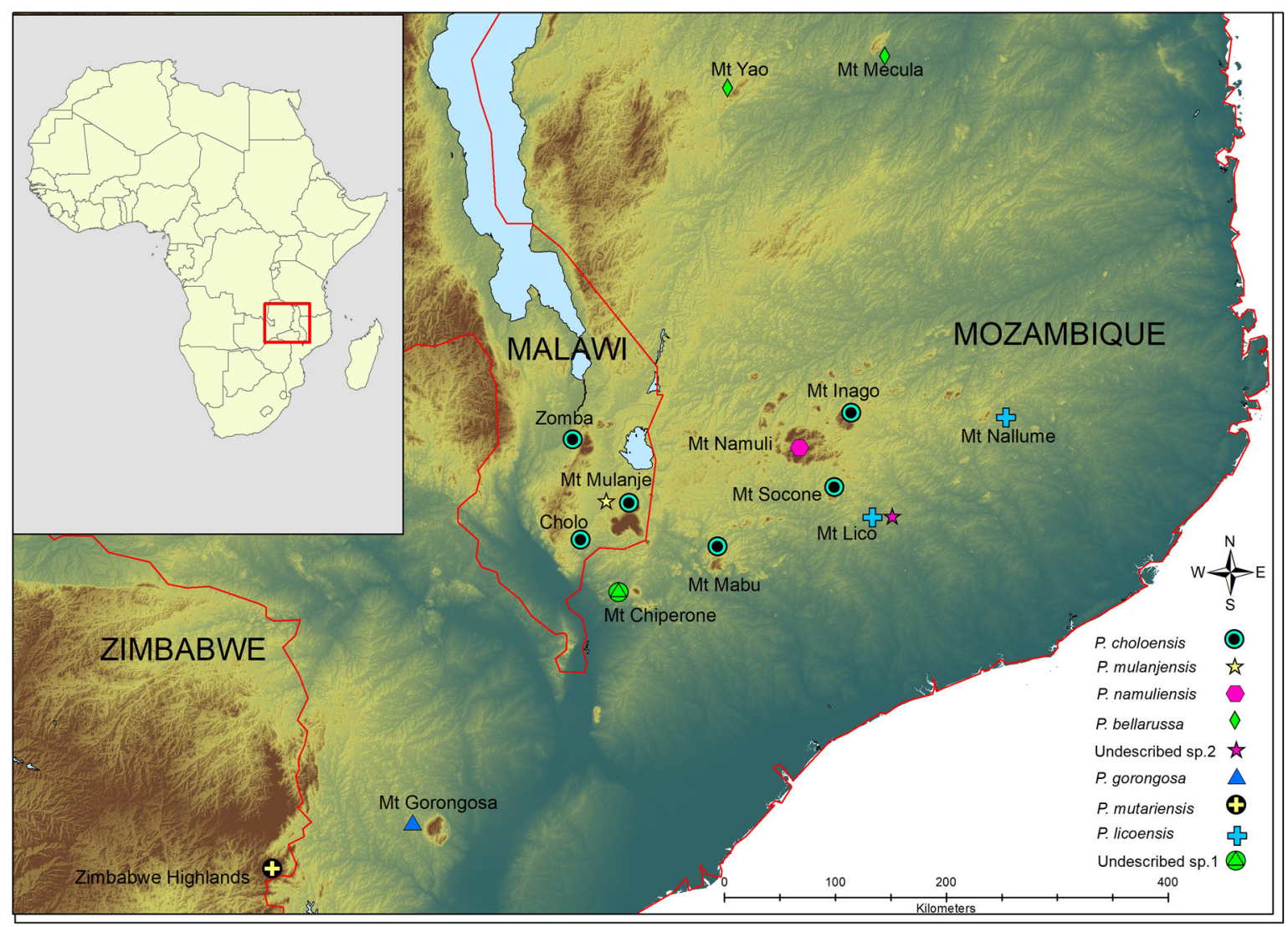

Fig. 8. Map showing the distribution of all the known and some as yet undescribed freshwater crab species from the 'sky islands' of Malawi, Mozambique and Zimbabwe. Two new freshwater species not yet described are listed as undescribed sp. 1 and 2 respectively. 
additional collection, specifically that of male specimens (Fig. 8). In addition, collectors need to sample and preserve animals in ethanol to render them useful for DNA based evolutionary studies.

\section{Acknowledgments}

The University of Stellenbosch is thanked for logical support to the first author, while the DNA sequencing unit at the Central Analytical Facility is thanked for sequencing. Erica Tovela of the Maputo Museum of Natural History is thanked for logistic support, the collecting permits and export permits. Ana Gledis da Conceição from the Gorongosa Institute is thanked for her support in collecting the freshwater crabs from Mount Lico. Theo Busschau and Aaron Barnes are thanked for their photographic skills.

\section{References}

Akaike H. 1973. Information theory as an extension of maximum likelihood principle. In: Petrov, B.N., Csake, F (eds) Second International Symposium on Information Theory: 267-281. Akademiai Kaido, Budapest.

Assefa A., Ehrich D., Taberlet P., Nemomissa S. \& Brochmann C. 2007. Pleistocene colonization of afro-alpine 'sky islands' by the arctic-alpine Arabis alpina. Heredity 99: 133-142.

https://doi.org/10.1038/sj.hdy.6800974

Barnes A., Reiss T. \& Daniel S.R. 2020. Systematics of the Peripatopsis clavigera species complex (Onycophora: Peripatopsidae) reveals cryptic cladogenic patterning: with the description of five new species. Invertebrate Systematics 34 (6): 569-590. https://doi.org/10.1071/IS19071

Bayliss J., Timberlake J., Branch W., Bruessow C., Collins S., Congdon C., Da Sousa C., Herrmann E., Dowsett R.J., Dowsett-Lemaire F., Fishpool L.D.C., Harris T., Georgiadis S., Liggitt B., Monadjem A., Patel I.H., Ribeiro D., Spottiswoode C.N., Taylor P., Willcock S. \& Smith P. 2014. The discovery, biodiversity, and conservation of Mabu forest - the largest mid-altitude rainforest in southern Africa. Oryx 48: 177-185. https://doi.org/10.1017/S0030605313000720

Bayliss J.L., Collins S.C. \& Congdon T.C.E. 2016. A new species of Iolaus Hübner, [1819] subgenus Epamera Druce, 1891 (Lepidoptera: Lycaenidae: Theclinae) from Mts Namuli and Mabu, Northern Mozambique. Metamorphosis 27: 23-30.

Bayliss J., Congdon T.C.E. \& Collins S.C. 2018. A new subspecies of Papilio (Princeps) pelodurus Butler, 1896 (Lepidoptera: Papilionidae: Papilioninae) from several mountains in northern Mozambique. Metamorphosis 29: 132-136.

Bayliss J., Brattström O., Bampton I. \& Collins S.C. 2019. A new species of Leptomyrina Butler, 1898 (Lepidoptera: Lycaenidae) from Mts Mecula, Namuli, Inago, Nallume and Mabu in Northern Mozambique. Metamorphosis 30: 19-24.

Branch W.R. \& Bayliss J. 2009. A new species of Atheris (Serpentes: Viperidae) from northern Mozambique. Zootaxa 2113: 41-54. https://doi.org/10.11646/zootaxa.2113.1.2

Branch W.R. \& Tolley K.A. 2010. A new species of chameleon (Sauria: Chamaeleonidae: Nadzikambia) from Mount Mabu, central Mozambique. African Journal of Herpetology 59: 157-172. https://doi.org/10.1080/21564574.2010.516275

Branch W.R., Bayliss J. \& Tolley K.A. 2014. Pygmy chameleons of the Rhampholeon platyceps complex (Squamata: Chamaeleonidae): description of four new species from isolated 'sky islands' of northern Mozambique. Zootaxa 3814: 1-36. https://doi.org/10.11646/zootaxa.3814.1.1

Branch W.R., Bayliss J., Bittencourt-Silva G.B., Conradie W., Engelbrecht H., Loader S.O., Menegon M., Nanvonomaquitxo C. \& Tolley K.A. 2019. A new species of tree snake (Dipsadoboa, Serpentes: 
Colubridae) from 'sky island' forest in northern Mozambique, with notes on other members of the Dipsadoboa werneri group. Zootaxa 4646: 541-563. https://doi.org/10.11646/zootaxa.4646.3.6

Bonnefille R. 2010. Cenozoic vegetation, climate changes and hominid evolution in tropical Africa. Global and Planetary Change 72: 390-411. https://doi.org/10.1016/j.gloplacha.2010.01.015

Busschau T., Conradie W. \& Daniels S.R. 2019. Evidence for cryptic diversification in a rupicolous forest-dwelling gecko (Gekkonidae: Afroedura pondolia) from a biodiversity hotspot. Molecular Phylogenetics and Evolution 139: 106549. https://doi.org/10.1016/j.ympev.2019.106549

Chace F.A. 1953. Zoological results of a fifth expedition to East Africa. VI. Decapod Crustacea. Bulletin of the Museum of Comparative Zoology 110: 427-443.

Available from https://www.biodiversitylibrary.org/page/2817476 [accessed 27 Aug. 2020].

Congdon T.C.E. \& Bayliss J. 2012. Butterflies of Mt Mecula and Mt Yao, Niassa Province, Northern Mozambique. Metamorphosis 23: 26-34.

Congdon C., Collins S. \& Bayliss J. 2010. Butterflies of south east Africa's mountains (Mozambique and Malawi). Metamorphosis 21: 45-107.

Conradie W., Bittencourt-Silva G.B., Farooq H.M., Loader S.P., Menegon M. \& Tolley K.A. 2018. New species of mongrel frogs (Pyxicephalidae: Nothophryne) for northern Mozambique inselbergs. African Journal of Herpetology 67: 61-85. https://doi.org/10.1080/21564574.2017.1376714

Cumberlidge N., Naskrecki P. \& Daniels S.R. 2016. Potamonautes gorongosa, a new species of potamonautid freshwater crab from Mozambique, southern Africa. Nauplius 24: e2016029.

https://doi.org/10.1590/2358-2936e2016029

Daniels S.R. 2011. Reconstructing the colonisation and diversification history of the endemic freshwater crab (Seychellum alluaudi) in the granitic and volcanic Seychelles Archipelago. Molecular Phylogenetics and Evolution 61: 534-542. https://doi.org/10.1016/j.ympev.2011.07.015

Daniels S.R. 2017. Sympatric colour morphs or distinct species? Examining species boundaries amongst two South African freshwater crabs (Decapoda: Potamonautidae: Potamonautes MacLeay, 1838) with the description of a new species. Journal of Crustacean Biology 37: 723-731.

https://doi.org/10.1093/jcbiol/rux087

Daniels S.R. \& Bayliss J. 2012. Neglected refugia of biodiversity: mountainous regions in Mozambique and Malawi yield two novel freshwater crab species (Potamonautidae: Potamonautes). Zoological Journal of the Linnean Society 164: 498-509. https://doi.org/10.1111/j.1096-3642.2011.00773.x

Daniels S.R. \& Klaus S. 2018. Divergent evolutionary origins and biogeographic histories of two freshwater crabs (Brachyura: Potamonautes) on the West African conveyer belt islands of São Tomé and Príncipe. Molecular Phylogenetics and Evolution 127: 119-128.

https://doi.org/10.1016/j.ympev.2018.05.016

Daniels S.R., Stewart B.A. \& Cook P.A. 2002a. Congruent patterns of genetic variation in a burrowing freshwater crab revealed by allozyme and mtDNA sequence analysis. Hydrobiologia 468: 171-179. https://doi.org/10.1023/A:1015203909091

Daniels S.R., Stewart B.A., Gouws G., Cunningham M. \& Matthee C.A. 2002b. Phylogenetic relationships of the southern African freshwater crab fauna (Decapoda: Potamonautidae: Potamonautes) derived from multiple data sets reveal biogeographic patterning. Molecular Phylogenetics and Evolution 25: 511-523. https://doi.org/10.1016/S1055-7903(02)00281-6

Daniels S.R., Cumberlidge N., Pérez-Losada M., Marijnissen S.A.E. \& Crandall K.A. 2006. Evolution of Afrotropical freshwater crab lineages obscured by morphological convergence. Molecular Phylogenetics and Evolution 40: 227-235. https://doi.org/10.1016/j.ympev.2006.02.022 
Daniels S.R., Phiri E.E. \& Bayliss J. 2014. Renewed sampling of inland aquatic habitats in southern Africa yields two novel freshwater crab species (Decapoda: Potamonautidae: Potamonautes). Zoological Journal of the Linnean Society 171: 356-369. https://doi.org/10.1111/zoj.12139

Daniels S.R., Phiri E.E., Klaus S., Albrecht C. \& Cumberlidge N. 2015. Multilocus phylogeny of the Afrotropical freshwater crab fauna reveals historical drainage connectivity and transoceanic dispersal since the Eocene. Systematic Biology 64: 549-567. https://doi.org/10.1093/sysbio/syv011

Daniels S.R., Busschau T. \& Cumberlidge N. 2019. Two new species of freshwater crabs of the genus Potamonautes MacLeay, 1838 (Decapoda: Brachyura: Potamonautidae) from the forests of KwaZuluNatal, South Africa. Journal of Crustacean Biology 39: 426-435. https://doi.org/10.1093/jcbiol/ruz024

Davidson A. \& Rex D. 1980. Age of volcanism and rifting in southwestern Ethiopia. Nature 283: 657658. https://doi.org/10.1038/283657a0

deMenocal P.B. 2004. African climate change and faunal evolution during the Pliocene-Pleistocene. Earth and Planetary Science Letters 220: 3-24. https://doi.org/10.1016/S0012-821X(04)00003-2

Demos T.C., Peterhans J.C.K., Agwanda B. \& Hickerson M.J. 2014. Uncovering cryptic diversity and refugial persistence among small mammal lineages across the Eastern Afromontane biodiversity hotspot. Molecular Phylogenetics and Evolution 71: 41-54. https://doi.org/10.1016/j.ympev.2013.10.014

Gouws G., Peer N. \& Perissinatto R. 2015. mtDNA lineage diversity of a potamonautid freshwater crab in KwaZulu-Natal, South Africa. Koedoe 57: 1-12. https://doi.org/10.4102/koedoe.v57i1.1324

Hofmeyr M.D., Vamberger M., Branch W., Schleicher A. \& Daniels S.R. 2017. Tortoise (Reptilia, Testudinidae) radiations in Southern Africa from the Eocene to the present. Zoologica Scripta 46: 380400. https://doi.org/10.1111/zsc.12223

Kissling W.D., Eiserhardt W.L., Baker W.J., Borchsenius F., Couvreur T.L.P., Baslev H. \& Svenning J-C. 2012. Cenozoic imprints on the phylogenetic structure of palm species assemblages worldwide. Proceedings of the National Academy of Sciences of the United States of America 109: 7379-7384. https://doi.org/10.1073/pnas.1120467109

Mittermeier R.A., Robles P., Hoffman M., Pilgrim J., Brooks T., Mittermeier C.G., Lamoreux J. \& da Fonseca G.A.B. 2004. Hotspots Revisited. Earth's Biologically Richest and Most Endangered Terrestrial Ecoregions. CEMEX, Agrupación Sierra Madre, S.C., Mexico City.

Nielsen S.V., Daniel S.R., Conradie W., Heinicke M.P. \& Noonan B.P. 2018. Multilocus phylogenetics in a widespread African anuran lineage (Brevicipitidae: Breviceps) reveals patterns of diversity reflecting geoclimatic change. Journal of Biogeography 45: 2067-2079. https://doi.org/10.1111/jbi.13394

Nylander J.A.A.A., Ronquist F., Huelsenbeck J.P. \& Nieves-Aldrey J.L. 2004. Bayesian phylogenetic analysis of combined data. Systematic Biology 53: 47-67. https://doi.org/10.1080/10635150490264699

Peer N., Perissinotto R., Gouws G. \& Miranda N.A.F. 2015. Description of a new species of Potamonautes MacLeay, 1838, from the iSimangaliso Wetland Park, South Africa. ZooKeys 503: 23-43.

https://doi.org/10.3897/zookeys.503.9532

Peer N., Gouws G., Lazo-Wasem E., Perissinotto R. \& Miranda N.A.F. 2017. Redescription of Potamonautes sidneyi (Rathbun, 1904) (Decapoda, Potamonautidae) and description of a new congeneric species from KwaZulu-Natal, South Africa. ZooKeys 657: 1-28.

https://doi.org/10.3897/zookeys.657.11623

Phiri E.E. \& Daniels S.R. 2013. Hidden in the highlands: the description and phylogenetic positioning of a novel endemic freshwater crab species (Potamonautidae: Potamonautes) from Zimbabwe. Invertebrate Systematics 27: 530-539. https://doi.org/10.1071/IS13012 
Phiri E.E. \& Daniels S.R. 2014. Disentangling the divergence and cladogenesis in the freshwater crab species (Potamonautidae: Potamonautes perlatus sensu lato) in the Cape Fold Mountains, South Africa, with the description of two novel cryptic lineages. Zoological Journal of the Linnaean Society 170: 310-332. https://doi.org/10.1111/zoj.12103

Phiri E.E. \& Daniels S.R. 2016. Multilocus coalescent species delimitation reveals widespread cryptic differentiation among Drakensberg mountain-living freshwater crabs (Decapoda: Potamonautes). Invertebrate Systematics 30: 60-74. https://doi.org/10.1071/IS15035

Portik D.M., Travers D., Bauer A.M. \& Branch W.R. 2013. A new species of Lygodactylus (Squamata: Gekkonidae) endemic to Mount Namuli, an isolated 'sky island' of northern Mozambique. Zootaxa 3710: 415-453. https://doi.org/10.11646/zootaxa.3710.5.2

Posada D. 2008. jModelTest: phylogenetic model averaging. Molecular Biology and Evolution 25: 1253-1256. https://doi.org/10.1093/molbev/msn083

Posada D. \& Buckley T.R. 2004. Model selection and model averaging in phylogenetics: advantages of the Akaike Information Criterion and Bayesian approaches over likelihood ratio tests. Systematic Biology 53: 793-808. https://doi.org/10.1080/10635150490522304

Reed S.K. \& Cumberlidge N. 2004. Notes on the taxonomy of Potamonautes obesus (A Milne-Edwards, 1868) and Potamonautes calcaratus (Gordon, 1929) (Brachyura: Potamoidea: Potamonautidae) from eastern and southern Africa. Zootaxa 418: 1-20. https://doi.org/10.11646/zootaxa.418.1.1

Ronquist F., Teslenko M., Van Der Mark P., Ayres D.L., Darling A., Höhna S., Larget B., Liu L., Suchard M.A. \& Huelsenbeck J.P. 2012. MrBayes 3.2: efficient Bayesian phylogenetic inference and model choice across a large model space. Systematic Biology 61: 539-542.

https://doi.org/10.1093/sysbio/sys029

Rose C., Polissar P.J., Tierney J.E., Filley T. \& deMenocal P.B. 2016. Changes in northeast African hydrology and vegetation associated with Pliocene-Pleistocene sapropel cycles. Philosophical Transactions of the Royal Society B 371: 20150243. https://doi.org/10.1098/rstb.2015.0243

Sepulchre P., Ramstein G., Fluteau F., Schuster M., Tiercelin, J-J. \& Brunet M. 2006. Tectonic uplift and eastern Africa aridification. Science 313: 1419-1423. https://doi.org/10.1126/science.1129158

Stamatakis A. 2006. RAxML-VI-HPC: maximum likelihood based phylogenetic analysis with thousands of taxa and mixed models. Bioinformatics 22: 2688-2690. https://doi.org/10.1093/bioinformatics/bt1446

Stewart B.A. 1997. Biochemical and morphological evidence for a new species of river crab Potamonautes parvispina sp. nov. (Brachyura, Potamonautidae). Crustaceana 70: 737-753.

https://doi.org/10.1163/156854097X00168

Swofford D.L. 2002. PAUP* Phylogenetic Analysis Using Parsimony (and other methods), Version 4.10. Illinois Natural History Survey, Champaign, Illinois.

Taylor P., Stoffberg S., Monadjem A., Schoema M.C., Bayliss J. \& Cotterill F.P.D. 2012. Four new bat species (Rhinolophus hildebrandtii complex) reflect Plio-Pleistocene divergence of dwarfs and giants across an Afromontane archipelago. PLoS ONE, 7: e41744. https://doi.org/10.1371/journal.pone.0041744

Thompson J.D., Gibson T.J., Plewniak F., Jeanmougin F. \& Higgins D.G. 1997. The CLUSTAL_X windows interface: flexible strategies for multiple sequence alignment aided by quality analysis tools. Nucleic Acids Research 25: 4876-4882. https://doi.org/10.1093/nar/25.24.4876

Tolley K.A., Chase B.M. \& Forest F. 2008. Speciation and radiations track climate transitions since the Miocene climatic optimum: a case study of southern African chameleons. Journal of Biogeography 35: 1402-1414. https://doi.org/10.1111/j.1365-2699.2008.01889.x 
Uno K.T., Polissar P.J., Jackson K.E. \& deMenocal P.B. 2016. Neogene biomarker record of vegetation change in eastern Africa. Proceedings of the National Academy of Sciences of the United States of America 113: 6355-6363. https://doi.org/10.1073/pnas.1521267113

Van Velzen R., Collins S.C., Brattström O. \& Congdon T.C.E. 2016. Description of a new species of Cymothoe Hübner, 1819 from northern Mozambique (Lepidoptera: Nymphalidae: Limenitidinae). Metamorphosis 27: 34-41.

Wood L.E. \& Daniels S.R. 2016. Genetic and morphological evidence for a new mountain-living freshwater crab species (Decapoda: Potamonautidae: Potamonautes) from the Western Cape province of South Africa. Invertebrate Systematics 30: 219-230. https://doi.org/10.1071/IS15051

Manuscript received: 24 April 2020

Manuscript accepted: 27 July 2020

Published on: 11 September 2020

Topic editor: Rudy Jocqué

Desk editor: Pepe Fernández

Printed versions of all papers are also deposited in the libraries of the institutes that are members of the EJT consortium: Muséum national d'histoire naturelle, Paris, France; Meise Botanic Garden, Belgium; Royal Museum for Central Africa, Tervuren, Belgium; Royal Belgian Institute of Natural Sciences, Brussels, Belgium; Natural History Museum of Denmark, Copenhagen, Denmark; Naturalis Biodiversity Center, Leiden, the Netherlands; Museo Nacional de Ciencias Naturales-CSIC, Madrid, Spain; Real Jardín Botánico de Madrid CSIC, Spain; Zoological Research Museum Alexander Koenig, Bonn, Germany; National Museum, Prague, Czech Republic. 